THE GREAT REVERSAL 



\section{THE \\ GREAT REVERSAL}

How America Gave Up on Free Markets

THOMAS PHILIPPON

The Belknap Press of Harvard University Press

CAMBRIDGE, MASSACHUSETTS

LONDON, ENGLAND 2019 
Copyright (c) 2019 by the President and Fellows of Harvard College

All rights reserved

Printed in the United States of America

First printing

Design by Dean Bornstein

Cover design: Tim Jones

9780674243101 (EPUB)

$9780674243118(\mathrm{MOBI})$

9780674243095 (PDF)

Many of the designations used by manufacturers and sellers to distinguish their products are claimed as trademarks. Where those designations appear in this book and Harvard University Press was aware of a trademark claim, then the designations have been printed in initial capital letters.

The Library of Congress has cataloged the printed edition as follows:

Names: Philippon, Thomas, author.

Title: The great reversal : how America gave up on free markets / Thomas Philippon. Description: Cambridge, Massachusetts : The Belknap Press of Harvard University

Press, 2019. | Includes bibliographical references and index.

Identifiers: LCCN 2019018624 | ISBN 9780674237544

Subjects: LCSH: Free enterprise-United States. | Free enterprise-Europe. |

Free enterprise-Political aspects-United States. | Markets-United States. |

Markets-Europe. | Competition-United States. | Competition-Europe. |

Lobbying-United States.

Classification: LCC HB95 .P53 2019| DDC 330.973-dc23

LC record available at https://lccn.loc.gov/2019018624 